Review Paper

\title{
Bioremediation of dyes using coconut parts via adsorption: a review
}

\author{
Mee Yoke Chong ${ }^{1} \cdot$ Yew Joon Tam ${ }^{2}$
}

Received: 7 September 2019 / Accepted: 6 January 2020 / Published online: 10 January 2020

(c) Springer Nature Switzerland AG 2020

\begin{abstract}
Coconut (Cocos nucifera) is a palm tree belonging to the Arecaceae family that possesses a thousand and one uses. Each part of the tree has it's uses and can be made into products. Also, various parts of the coconut tree have been utilized to remove various types of dyes from water and waste water via chemical, physical and biological methods. Adsorption is one of the widely used physical methods over their counterparts owing to cost efficiency and ease in handling. The key parameters for the adsorption process are the initial concentration of adsorbate, dosage of adsorbent, the $\mathrm{pH}$ and contact time. Additionally, the kinetic parameters, equilibrium isotherm and thermodynamics of the adsorption of dyes on the adsorbent were explored.
\end{abstract}

Keywords Coconut · Dyes · Adsorption · Kinetic parameters · Equilibrium isotherm · Thermodynamic

\section{Introduction}

In this modern era, water pollution in Malaysia has escalated owing to the growing numbers of polluted rivers from 2006 to 2010 [1]. The major point sources of polluted rivers in Malaysia arises from the sewage treatment plants (54.1\%), manufacturing (38.7\%), agro-based industries $(2.8 \%)$, and animal farms (4.5\%). Also, the rivers in Malaysia are heavily contaminated by the diffused (non-point) sources such as agricultural activities and surface runoffs $[2,3]$. According to Afroz and Rahman (2017a), the manufacturing industries comprise of food and beverage industry $(23.7 \%)$, electricity and electronics $(11.4 \%)$, chemical industry (11.2\%), paper industry (8.8\%) finishing industry $(7.4 \%)$, textile $(5.3 \%)$, effluents from oil palm industry (5.3\%), effluents from rubber industry (2.0\%) and others (24.9\%) which have contributed to the rivers pollution in Malaysia. Although textile industry does not lead the rivers pollution but the industry is mushrooming rapidly due to the high demand from the consumers for its finished goods. The industry alone produces tons of contaminants such as dyes into the stream during textile fiber dyeing and finishing processes [1].

Dye molecules are organic compounds that interact with the functional groups on the surfaces of the fabrics to impart color as well as the ability to withstand the action of detergents [4]. Each dye molecule is divided into two parts, namely chromophores and auxochromes [5]. Chromophores in the dye molecule are constructed by the delocalized electron-withdrawing groups (i.e. alkenes, carbonyl, nitro, $-\mathrm{C}=\mathrm{N}-,-\mathrm{N}=\mathrm{N}-$ and $-\mathrm{N}=\mathrm{O}$ ) that are responsible for the color of the dye. These delocalized electrons absorb visible region in the electromagnetic radiation. The amount of energy absorbed depends on the amount of double bond in the dye compound. Subsequently, the absorbed energy is used to excite the electrons to a higher energy level. At high energy level, the electrons are unstable, hence the electron falls to lower

Electronic supplementary material The online version of this article (https://doi.org/10.1007/s42452-020-1978-y) contains supplementary material, which is available to authorized users.

\footnotetext{
$\triangle$ Mee Yoke Chong, meeyoke.chong@newinti.edu.my | ${ }^{1}$ Centre for American Education, INTI International University, Persiaran Bandar Baru Nilai, 71800 Nilai, Malaysia. ${ }^{2}$ Faculty of Health and Life Sciences, Department of Biotechnology, INTI International University, Persiaran Bandar Baru Nilai, 71800 Nilai, Malaysia.
} 
energy level by emitting ray. The emission of rays signified the color of the dye observed [6]. On the other hand, the auxochromes that attributes to the intensity of the color is formed by the electron-donating groups (i.e. amines, carboxylic acids, sulphonic acid and alcohols) [7]. Aside from determining the intensity of the color, the auxochromes groups are accountable for the solubility in the water and the bonding with the fabric [8].

There are several ways to classify dyes, namely: (a) natural and synthetic [9, 10], (b) chromophores [11] and (c) applications [11, 12]. Generally, dyes are predominantly divided into three categories, namely [13]: (a) anionic, (b) cationic and (c) non-ionic. Anionic dyes are negatively charged organic molecules. The presence of negative charge on the dye molecule is due to the oxygen atom that has great electronegativity towards the electron rich area in the carbonyl group for the entire chromophore system [14]. The formation of negative charge on the Acid Blue 25 is shown in Figure A1, Supporting Information. Cationic dyes are developed in lieu to the formation of positive charge which forms great interaction with negatively charged fabric [15]. Non-ionic dyes are neutral in nature because the electron rich area in the chromophore is shared equally between two identical atoms [16]. The non-polar covalent bond formed between two nitrogen atoms in the chromophore system for Disperse Orange 37 is shown in Figure A2, Supporting Information. The examples of non-ionic dyes are disperse and vat that contains either azo or anthraquinone group attached to benzene ring in their chromophore system [17].

Different types of dyes possess different disadvantages that cause severe harm to the environment and human health. Therefore, various methods (i.e. chemical, physical and biological) have been proposed to overcome this problem [18]. Chemical treatment methods consisted of electrolysis and oxidation. Oxidation is a method to remove dye by utilizing oxidizing agents (i.e. ozone, ultra violet, titanium(IV) oxide, fenton, photo-phenton and hydrogen peroxide). These oxidants trap the dye molecules through the bonding with the radicals [19]. However, the technique produces harmful decomposition products such as formate and benzene sulfonate ions as by-products [20]. Electrolysis is a process to break down the dye molecules by using electricity [21]. The process is costly due to the electricity consumed and electrodes replacements [22]. In this process, the current is used to breakdown the dye molecules into free ions. The ions produced then flow to the electrodes which eventually be oxidized and reduced to less harmful products. On the contrary, the use of microorganisms such as bacteria, fungi, yeast and algae in the adsorption of dyes molecules is environmental friendly and low cost [20]. For instance, it does not require larger space to construct robust equipment for the decolorization of dyes as well as less toxic decomposition products. However, the time needed to obtain a pure culture is relatively long. The mechanism to treat the effluents from the waste water depends on the type of microorganisms used. An alive microorganism will be immobilized on a support containing media for continuous growth. The microorganism ingests the harmful dye molecules through enzymes secretions in the intracellular cell. Subsequently, the microorganism will then excrete the less harmful digested product to the environment [23]. On the other hand, a dead microorganism removes the dye molecules from the waste water through adsorption technique. The physical techniques used to treat the dye molecules from the waste water consists of adsorption, coagulation/flocculation, filtration, reverse osmosis and electro-flotation. These techniques share the same mechanism which is in the use of chelating or coagulant agents to precipitate out the harmful dye molecules from the waste water through the formation of flocs or sediments. Electro-flotation is an improvise technique combining coagulation/flocculation and electricity. It traps the dye molecule through coagulation which will later be broken down to less harmful products by electric current. It is cheap, energy efficiency, safe, and versatile [24].

Still, adsorption is in favor over their counterpart methods due to low cost, hassle free and availability [25]. Basically, adsorption is an entrapment of dye molecules by the adsorbent through both physical and chemical interactions. This method relies strongly on the adsorbate (types of auxochromes) and criteria of adsorbents used (i.e. particle size, surface area, temperature, $\mathrm{pH}$ and contact time) [26]. Various adsorbents such as activated carbons, clays, metal oxides and metal hydroxides have been explored to remove dye molecules from waste water [27]. Activated carbon has been widely used because of its larger surface area and easy availability but it's production cost is high. Similarly, Elmoubarki et al. [18] mentioned that the lamellar structure of the clay creates larger surface area than the activated carbon in the removal of dyes from the contaminated water [18]. Meanwhile, metal oxides and hydroxides gained their popularity due the mesosphere structure created (i.e. flower, rod and etc.) which enable them to enhance the adsorption capacity [28].

The main goal of this review is to provide a summary of recent information concerning the use of coconut parts as adsorbents for dyes in wastewaters. Malaysia remains one of the world's top ten coconut-producing countries, and coconut is the country's fourth most important crop after oil palm, rubber and rice. Malaysia produces at least 168 million tons of biomass, including timber and oil palm waste, rice husks, coconut trunk fibers, municipal waste and sugarcane waste annually. Various coconut parts were modified to treat heavy metals in the waste water [29-31], 
organic compounds in the water stream (i.e. butylparaben, benzene, toluene, carbofuran) [32-34], carbon dioxide gaseous from the flue gas [35] and inorganic pollutants from the drinking water [36-38].

\section{Coconut shell}

Coconut shell was the predominantly used part for the removal of dyes from the waste water. There are three ways to modify the coconut shell prior to the removal of dyes, namely activated carbon [39-43], acid or base treatment $[44,45]$, and as immobilizer for the bacteria [46]. Table 1 summarizes the physical parameters, adsorption kinetic and equilibrium isotherm of the modified coconut shell.

\subsection{Physical parameters}

\subsubsection{Contact time}

Among the parameters mentioned, contact time is the time for the adsorbent to interact with the adsorbate. It is a niche parameter in order to develop a cost effective method. Figure 1 demonstrates the effect of contact time for the uptake of Methylene Blue by the activated carbon using coconut shell treated with $\mathrm{NaOH}$ via hydrothermal treatment [42]. Based on Fig. 1, the time needed to adsorb 25 and $50 \mathrm{mg} / \mathrm{L}$ of Methylene Blue is less than $30 \mathrm{~min}$. The contact time increased by four times to $2 \mathrm{~h}$ for the adsorption of 75 and $100 \mathrm{mg} / \mathrm{L}$. As the concentration of Methylene Blue increased to 150,200 and $250 \mathrm{mg} / \mathrm{L}$, the adsorbent requires $6 \mathrm{~h}$ to achieve a steady maximum adsorption capacity. The dyes were adsorbed rapidly at initial stage owing to huge amount of available sites and the number of active sites increases with the concentration [47]. However, the available sites in adsorbent will eventually be saturated thereafter achieving a steady state [48].

\subsection{2 $\mathrm{pH}$}

The $\mathrm{pH}$ of the adsorbate is another important parameter that affects the adsorption process. The interaction between dye molecule and adsorbent at different $\mathrm{pH}$ is shown in Figure A3, Supporting Information. At low $\mathrm{pH}$, the concentration of $\mathrm{H}^{+}$ions are high. Hence, anionic (negatively charged) dye interacts well in acidic condition owing to ion-dipole interaction. In fact, the adsorption of anionic dyes will be elevated by the impregnation of phosphoric acid on the dried coconut shell prepared by Ndifor-Angwafor et al. [17] because the $\mathrm{H}^{+}$ions on the activated carbon provides sites to adsorb anionic dye molecules [45]. The result is in well agreement with the research conducted by Jóźwiak et al. (2018) [44]. On the contrary, Islam et al. [42] modified the activated carbon based coconut shell via hydrothermal and sodium hydroxide (COSHTC3) treatments which facilitates more negatively charged sites on its surface for the adsorption of cationic dyes. In basic condition, the concentration of $\mathrm{OH}^{-}$ions is high and hence it enables the entrapment of cationic dyes. The interaction was strengthened by the base modification on the activated carbon by coconut shell because it facilitates more available sites for cationic dyes [42].

Figure 2 depicts the effect of $\mathrm{pH}$ for the adsorption of Methylene Blue by COSHTC3. It indicates that the best $\mathrm{pH}$ for the adsorption of Methylene Blue by COSHTC3 is 9 because it achieves the maximum adsorption capacity of $107 \mathrm{mg} / \mathrm{g}$. The adsorption capacity of Methylene Blue by COSHTC3 is low at both pH lesser and greater than 9. This is because at $\mathrm{pH}$ greater than 9 , there are excessive hydroxide ions causes repulsion that hinders the smooth adsorption of cationic dye on the COSHTC3 [49]. Meanwhile, the low adsorption of Methylene Blue by COSHTC3 is low at $\mathrm{pH}$ lesser than 9 and this is because the sites provided by the adsorbent are taken up by the $\mathrm{H}^{+}$ions that is smaller than cationic dye molecules $[44,50]$.

\subsection{Equilibrium isotherm models}

\subsubsection{Langmuir}

Langmuir isotherm model states that a monolayer of the entire surface of the adsorbent has identical sorption capacity (homogeneous) with limited active sites for the non-interacting adsorbate. The Langmuir isotherm model can be written as follows [51]:

$q_{e}=\frac{q_{m} K_{L} C_{e}}{1+K_{L} C_{e}}$

where $q_{e}$ is the amount of adsorbate per unit mass of adsorbent at equilibrium $(\mathrm{mg} / \mathrm{g}), K_{L}$ is the adsorption capacity constant $(\mathrm{L} / \mathrm{g}), C_{e}$ is the concentration of adsorbate at equilibrium ( $\mathrm{mg} / \mathrm{L})$ and $q_{m}$ is the maximum adsorption capacity $(\mathrm{mg} / \mathrm{g})$.

The Langmuir isotherm model is rearranged for plotting the graph and it can be written as follows:

$\frac{C_{e}}{q_{e}}=\frac{1}{q_{m}}\left(C_{e}\right)+\frac{1}{q_{m} K_{L}}$

When a graph of $\frac{C_{e}}{q_{e}}$ is plotted against $C_{e^{\prime}}$ a linear graph is acquired with regression linear coefficient, $R^{2}$, close to unity. The $q_{m}$ and $K_{L}$ are obtained from the gradient and intercept of the graph. Both the gradient and intercept of the graph represent the values for $\frac{1}{q_{m}}$ and $\frac{1}{q_{m} K_{L}}$, respectively. 
Table 1 Physical parameters, adsorption kinetic and equilibrium isotherm of the modified coconut shell

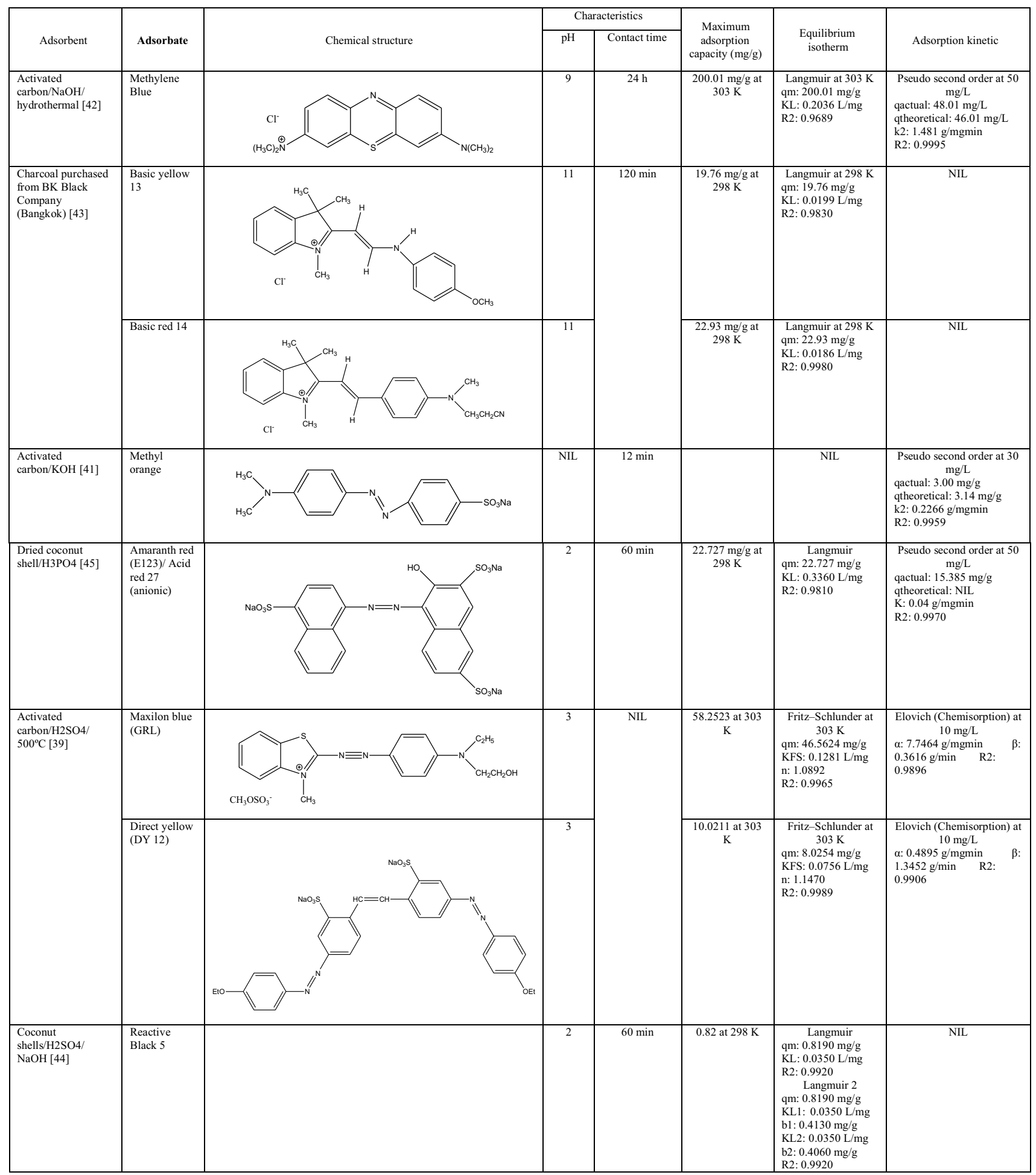

The highest adsorption capacity is observed by the adsorption of $200.01 \mathrm{mg}$ of Methylene Blue by $1 \mathrm{~g}$ of activated carbon prepared by using coconut shell modified by
$\mathrm{NaOH}$ and hydrothermal treatments [42]. Subsequently, the research conducted by Srisorrachatr et al. [43] successfully adsorbed $22.93 \mathrm{mg}$ and $19.76 \mathrm{mg}$ of Basic Red and 
Table 1 (continued)

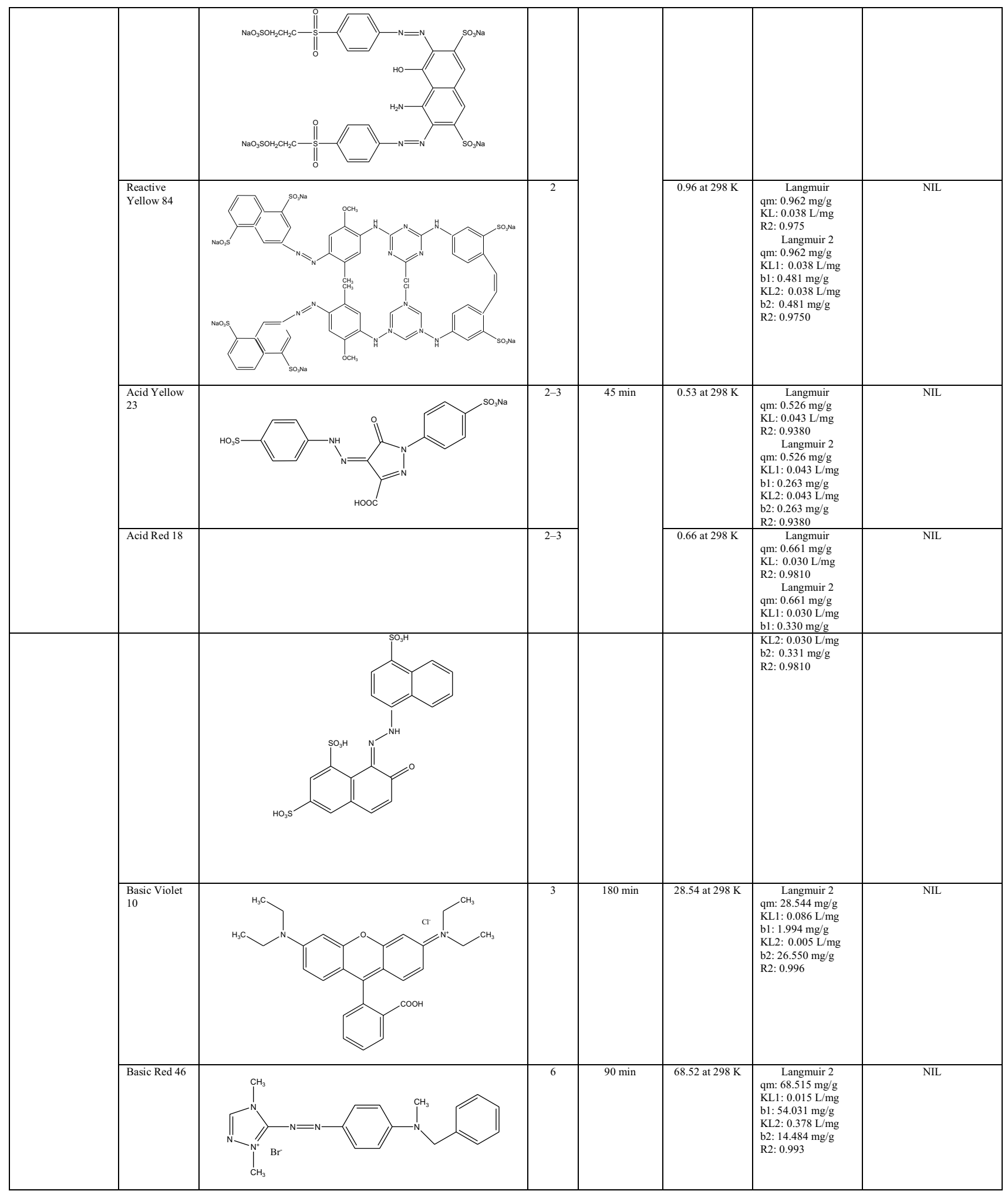

Basic Yellow dyes, respectively for every gram of charcoal prepared by coconut shell procured from BK Black company [43]. Nonetheless, the only anionic type of dye that fits Langmuir isotherm model along with highest adsorption capacity can be observed by the adsorption of $22.727 \mathrm{mg}$ of Amaranth Red by $1 \mathrm{~g}$ of dried coconut shell impregnated with $\mathrm{H}_{3} \mathrm{PO}_{4}$ [45]. 


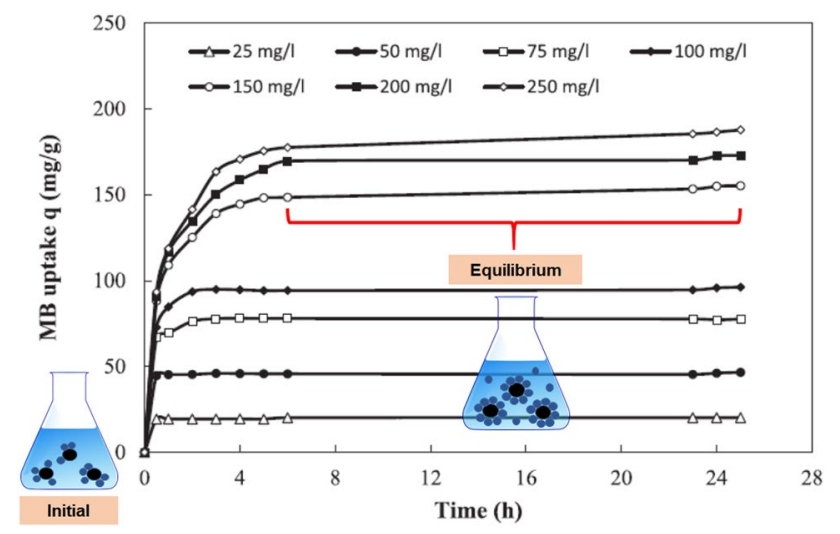

Fig. 1 The effect of contact time for the uptake of Methylene Blue by the activated carbon using coconut shell treated with $\mathrm{NaOH}$ via hydrothermal [42]

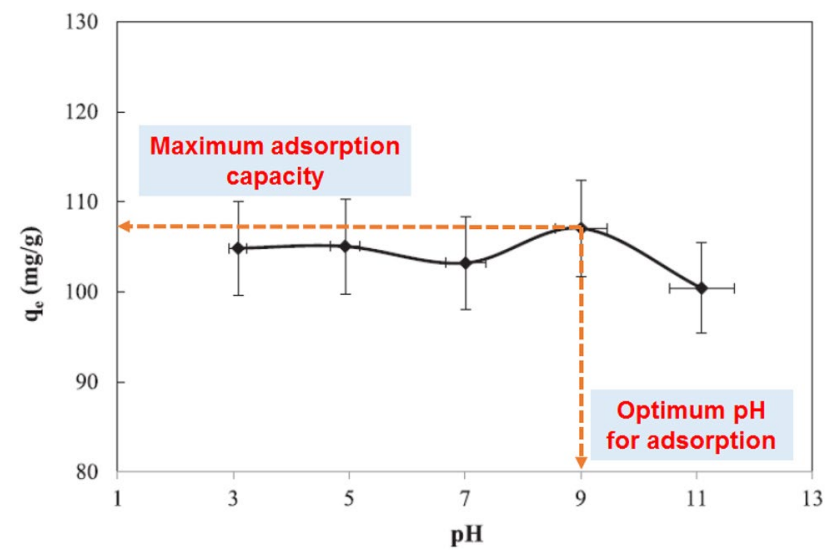

Fig. 2 The effect of $\mathrm{pH}$ for the adsorption of Methylene Blue by COSHTC3 [42]

\subsubsection{Fritz-Schlunder}

The Fritz-Schlunder isotherm model is an empirical threeparameter isotherm combining the Langmuir and Freundlich isotherms. The Fritz-Schlunder isotherm model can be written as follows [52]:

$q_{e}=\frac{K_{F S} q_{m} C_{e}}{1+q_{m} C_{e}^{n}}$

where $q_{e}$ is the amount of adsorbate per unit mass of adsorbent at equilibrium ( $\mathrm{mg} / \mathrm{g}), C_{e}$ is the concentration of the adsorbate at the equilibrium (mg/L), $q_{m}$ is the maximum adsorption capacity $(\mathrm{mg} / \mathrm{g}), K_{F S}$ is the Fritz-Schlunder model constant and $n$ is the Fritz-Schlunder(III) model exponent. When a graph of $q_{e}$ is plotted against $C_{e}$, a linear graph is acquired with regression linear coefficient, $R^{2}$, close to unity. The research conducted by Aljeboree et al.
[39] fits Fritz-Schlunder and it was found that every $1 \mathrm{~g}$ of activated carbon prepared using coconut shell impregnated with $\mathrm{H}_{2} \mathrm{SO}_{4}$ at $500{ }^{\circ} \mathrm{C}$ adsorbed $46.5624 \mathrm{mg}$ and $8.0254 \mathrm{mg}$ of Maxilon Blue GRL and Direct Yellow DY12 dyes, respectively [39]. The Maxilon Blue GRL dye interacts greatly with the activated carbon impregnated with $\mathrm{H}_{2} \mathrm{SO}_{4}$ because the dye offers a lone pair of electron to the $\mathrm{H}^{+}$ions on the surface of the adsorbent. Likewise, the presence of $\mathrm{CH}_{3} \mathrm{OSO}_{3}{ }^{-}$ions creates ion-dipole interaction with protons, $\mathrm{H}^{+}$, on the surface of the adsorbent. In contrast, the stable delocalized electron and steric hindrance on the direct yellow dye hampered the interaction with the adsorbent. The result is reinforced by the greater $K_{F S}$ value owned by the adsorption of Maxilon Blue GRL (0.1281 L/ $\mathrm{mg}$ ) compared to $K_{F S}$ of the adsorption of Direct Yellow DY12 $(0.0756 \mathrm{~L} / \mathrm{mg})$ by the activated carbon impregnated with $\mathrm{H}_{2} \mathrm{SO}_{4}$.

\subsubsection{Langmuir double (Langmuir 2)}

The Langmuir double (Langmuir 2) isotherm model states that the adsorbent provides either one or two types of active sites for the adsorbate. The Langmuir double can be written as follows [53]:

$q_{e}=\frac{q_{\max 1} K_{L 1} C_{e}}{1+K_{L 1} C_{e}}+\frac{q_{\max 2} K_{L 2} C_{e}}{1+K_{L 2} C_{e}}$

where $q_{e}$ is the maximum adsorption capacity at equilibrium ( $\mathrm{mg} / \mathrm{g}), C_{e}$ is the concentration of adsorbate at equilibrium (mg/L), $q_{\max 1}$ is the maximum adsorption capacity for Langmuir type $1(\mathrm{mg} / \mathrm{g}), q_{\max 2}$ is the maximum adsorption capacity for Langmuir type $2(\mathrm{mg} / \mathrm{g}), K_{L 1}$ is the constant for Langmuir type $1(\mathrm{~L} / \mathrm{mg})$ and $K_{L 2}$ is the constant for Langmuir type 2 ( $\mathrm{L} / \mathrm{mg})$. The adsorbent provides one type of active sites for the adsorbate if the $q_{\max 1}=q_{\max 2}$ as well as $K_{L 1}=K_{L 2}$. It can be seen by the adsorption of anionic dyes (Reactive Black 5, Reactive Yellow 84, Acid Yellow 23 and Acid Red 18) by the coconut shell modified with $\mathrm{H}_{2} \mathrm{SO}_{4}$ and $\mathrm{NaOH}$ [44]. On the other hand, the adsorbent provides two types of active sites if $q_{\max 1} \neq q_{\max 2}$ as well as $K_{L 1} \neq K_{L 2}$. The scenario is manifested by the adsorption of cationic dyes (Basic Violet 10 and Basic Red 46) on the coconut shell modified with $\mathrm{H}_{2} \mathrm{SO}_{4}$ and $\mathrm{NaOH}$ (Jóźwiak et al., 2018). The $q_{\max 1}, q_{\max 2}, K_{L 1}$ and $K_{L 2}$ for adsorption of Basic Violet 10 are $1.994 \mathrm{mg} / \mathrm{g}, 26.550 \mathrm{mg} / \mathrm{g}, 0.086 \mathrm{~L} / \mathrm{mg}$ and $0.005 \mathrm{~L} / \mathrm{mg}$, respectively. Meanwhile the $q_{\max 1}, q_{\max 2}$, $K_{L 1}$ and $K_{L 2}$ for adsorption of Basic Red 46 are $54.031 \mathrm{mg} / \mathrm{g}$, $14.484 \mathrm{mg} / \mathrm{g}, 0.015 \mathrm{~L} / \mathrm{mg}$ and $0.378 \mathrm{~L} / \mathrm{mg}$, respectively. Based on the result, the adsorbent with two active sites produces higher maximum adsorption capacity than the adsorbent with one active site. This is because each cationic dye molecule accommodates two sites (a group of 
Lewis base by tertiary amine and a group of Lewis acid by the quaternary amine) to create synergistic effect with the surface of the adsorbent. However, the modified coconut shell adsorbs Basic Red 46 better than Basic Violet 10 because Basic Red 46 portrays lesser steric hindrance due to it's small molar mass $(401 \mathrm{~g} / \mathrm{mol})$.

\subsection{Adsorption kinetic models}

\subsubsection{Lagergren's pseudo second order}

Lagergren model is used to evaluate the equilibrium time needed for the transfer of adsorbate on the adsorbent. The factors affecting the overall mass transfer are [54]:

(a) Bulk diffusion Diffusion of the solute from the bulk solution to the film (surrounding the particle)

(b) External surface diffusion Diffusion across the film to the particle surface.

(c) Pore diffusion Diffusion from the surface to the internal sites.

According to Table 2, most of the adsorption processes by the modified coconut shell fit Lagergren's pseudo second order which is based on the rate limiting step for chemical sorption mechanism. The linear expression of Lagergren's pseudo second order is as follows [54]:

$\frac{t}{q_{t}}=\left(\frac{1}{q_{e}}\right) t+\frac{1}{k_{2} q_{e}^{2}}$

where $q_{t}$ is the amount of adsorbate at any time $(\mathrm{mg} / \mathrm{g}), q_{e}$ is the amount of adsorbate at equilibrium $(\mathrm{mg} / \mathrm{g}), k_{2}$ is the rate constant for the pseudo second order ( $\mathrm{g} / \mathrm{mg} \mathrm{min}$ ) and $t$ is the time taken for the adsorption process until it reaches equilibrium ( $\mathrm{min})$. When a graph of $\frac{t}{q_{t}}$ is plotted against $t$, a linear graph is acquired with regression linear coefficient, $R^{2}$, close to unity. Additionally, the consistency of both the theoretical and experimental values for $q_{e}$ confirms the adsorption kinetic process obeyed pseudo second order [55]. It was proven from the research conducted by Islam et al. [41, 42]. The $q_{\text {actual }}$ for the adsorption of Methylene Blue by the activated carbon prepared using coconut shell impregnated with $\mathrm{NaOH}$ via hydrothermal method is $48.01 \mathrm{mg} / \mathrm{L}$. The value differs by $4.35 \%$ from the $q_{\text {theoretical }}$ value that is $46.01 \mathrm{mg} / \mathrm{L}$. Similarly, the adsorption of Methyl Orange by the activated carbon prepared through coconut shell and $\mathrm{KOH}$ treatment obtained

Table 2 Results for the adsorption of Methylene Blue by fallen coconut leaves (untreated and treated)

\begin{tabular}{|c|c|c|c|c|}
\hline \multirow[t]{3}{*}{ Characteristics } & \multicolumn{4}{|l|}{ Adsorbents } \\
\hline & \multirow{2}{*}{$\begin{array}{l}\text { Untreated } \\
\text { UCL [64] }\end{array}$} & \multicolumn{3}{|l|}{ Treated } \\
\hline & & PCL [65] & HACL [66] & FACL [67] \\
\hline Adsorbate & \multicolumn{4}{|l|}{ Methylene Blue } \\
\hline Initial pH & 8.65 & $5-6$ & 5.60 & 5.60 \\
\hline Average pore size $(\AA ̊)$ & NIL & 36.50 & 73.94 & $\mathrm{NIL}$ \\
\hline Maximum adsorption capacity (mg/g) & 112.35 at $302 \mathrm{~K}$ & 250.00 at $303 \mathrm{~K}$ & 357.14 at $300 \mathrm{~K}$ & 66.00 at $303 \mathrm{~K}$ \\
\hline Adsorption equilibrium isotherms & \multicolumn{4}{|l|}{ Langmuir } \\
\hline$q_{m}(m g / g)$ & 112.35 & 250.00 & 357.14 & 66.00 \\
\hline $\mathrm{K}_{\mathrm{L}}(\mathrm{L} / \mathrm{mg})$ & 0.0792 & 0.2200 & 0.2750 & 0.0400 \\
\hline $\mathrm{R}^{2}$ & 0.9963 & 0.9822 & 0.9950 & 0.9900 \\
\hline Adsorption kinetic & \multicolumn{4}{|c|}{ Pseudo-second order (50 mg/L) } \\
\hline $\mathrm{k}_{2}(\mathrm{~g} / \mathrm{mg} \min )$ & 0.0292 & 0.0470 & 0.0002 & 0.0002 \\
\hline $\mathrm{q}_{\mathrm{e}}$ theoretical $(\mathrm{mg} / \mathrm{g})$ & 26.53 & 21.30 & 285.71 & 33.11 \\
\hline $\mathrm{q}_{\mathrm{e}}$ actual $(\mathrm{mg} / \mathrm{g})$ & 26.19 & 21.00 & 269.74 & 33.05 \\
\hline $\mathrm{R}^{2}$ & 0.9999 & 1.0000 & 0.9980 & 0.9990 \\
\hline & & \multicolumn{3}{|l|}{$\begin{array}{l}\text { Weber-Morris intraparticle dif- } \\
\text { fusion model ( } 50 \mathrm{mg} / \mathrm{L})\end{array}$} \\
\hline $\mathrm{K}_{\mathrm{id}}\left(\mathrm{mg} / \mathrm{gmin}^{1} / 2\right)$ & & \multicolumn{3}{|l|}{2.3} \\
\hline$C(\mathrm{mg} / \mathrm{g})$ & & \multicolumn{3}{|l|}{10.56} \\
\hline $\mathrm{R}^{2}$ & & \multicolumn{3}{|l|}{0.9420} \\
\hline \multicolumn{5}{|l|}{ Thermodynamics study } \\
\hline$\Delta \mathrm{G}$ at $300 \mathrm{~K}(\mathrm{~kJ} / \mathrm{mol})$ & NIL & -5.95 & -55.11 & $\mathrm{NIL}$ \\
\hline$\Delta \mathrm{H}^{\circ}(\mathrm{kJ} / \mathrm{mol})$ & NIL & - 107.7 (exothermic) & 21.91 (endothermic) & NIL \\
\hline$\Delta \mathrm{S}^{\circ}(\mathrm{kJ} / \mathrm{mol} \mathrm{K})$ & NIL & 0.3750 & 0.1096 & NIL \\
\hline
\end{tabular}


$3.00 \mathrm{mg} / \mathrm{g}$ via experimental testing and $3.14 \mathrm{mg} / \mathrm{g}$ via theoretical calculation. The $q_{e}$ and $k_{2}$ are obtained from the gradient and intercept of the graph. Both the gradient and intercept of the graph represent the values for $\frac{1}{q_{e}}$ and $\frac{1}{k_{2} q_{e}^{2}}$, respectively.

\subsubsection{Elovich (chemisorption)}

The kinetic adsorption of Maxilon Blue GRL and Direct Yellow DY 12 by the activated carbon modified from coconut shells impregnated with $\mathrm{H}_{2} \mathrm{SO}_{4}$ portrays the Elovich equation. It has been used for slow and heterogeneous chemical adsorption process and the equation is as follows [56]:

$q_{t}=\left(\frac{1}{\beta}\right) \ln (\alpha \beta)+\left(\frac{1}{\beta}\right) \ln (t)$

where $q_{t}$ is the maximum adsorption capacity at time $t$ $(\mathrm{mg} / \mathrm{g}), t$ is contact time ( $\mathrm{min}), \alpha$ is the initial adsorption rate $(\mathrm{mg} / \mathrm{gmin})$ and $\beta$ is the desorption constant $(\mathrm{g} / \mathrm{min})$. When a graph of $q_{t}$ is plotted against $\ln (t)$, a linear graph is acquired with regression linear coefficient, $R^{2}$, close to unity. The $\alpha$ and $\beta$ are obtained from the gradient and intercept of the graph. Both the gradient and intercept of the graph represent the values for $\left(\frac{1}{\beta}\right)$ and $\left(\frac{1}{\beta}\right) \ln (\alpha \beta)$, respectively. The research conducted by Aljeboree et al. [39] obeyed the Elovich equation (chemisorption process) because the $R^{2}$ value obtained was close to unity [40]. The adsorption of Maxilon Blue GRL by the modified coconut shell attained higher initial adsorption rate $(\alpha=7.7464 \mathrm{~g} /$ $\mathrm{mg} \mathrm{min}$ ) than Direct Yellow DY12 ( $\alpha=0.4895 \mathrm{~g} / \mathrm{mg} \mathrm{min}$ ). Therefore, the adsorption of Maxilon Blue GRL achieves greater adsorption capacity than Direct Yellow DY12. Subsequently, the desorption rate of Direct Yellow DY12 is faster $(\beta=1.3452 \mathrm{~g} / \mathrm{min})$ than Maxilon Blue $\mathrm{GRL}$ $(\beta=0.3616 \mathrm{~g} / \mathrm{min})$.

\section{Coconut frond}

Coconut fronds are the stiff mid-ribs of coconut leaves. A frond is divided into a few components, which are the frond base, cushion, keel, petiole, pinnae and rachis. The cushion part of a coconut frond is the component used as adsorbent by Mohammad et al. [57]. The cushion was rinsed with distilled water prior to dry under sunlight for 2 days. Later on, the cushion was cut into small pieces and was dried under the sunlight for 2 days. Finally, the dried cushion was grinded and sieved into different particle sizes $(0.125,0.300$, and $0.710 \mathrm{~mm})$ before being used as adsorbent for Malachite Green ( $\mathrm{N}$-methylated diaminotriphenylmethane), a cationic dye adsorption. The parts of the coconut fronds and the chemical structure of Malachite Green are depicted in Figure A4(a) and (b), Supporting Information, respectively.

\subsection{Physical parameter (particle size of adsorbent)}

Figure 3 depicts the characteristics of coconut frond in the adsorption of Malachite Green. The highest removal percentage of dye was observed by the smallest particle size $(0.125 \mathrm{~mm})$ of coconut frond because it provides larger surface area for adsorption as shown in Fig. 3a. Moreover, Rani et al. (2017) mentioned if the adsorbent has a particle size smaller than $0.125 \mathrm{~mm}$, the particles entangle and it decreases the availability of the active sites on the surface for adsorption [58]. Based on Fig. 3b, the most optimum contact time for the removal percentage to reach equilibrium is $16 \mathrm{~h}$. If the contact time is longer than $16 \mathrm{~h}$, the active sites on the adsorbent will be saturated and thus the removal percentage of dyes will decrease. On the other hand, the adsorption process is incomplete if the contact time is insufficient (less than $16 \mathrm{~h}$ ). Generally, the adsorption of cationic dye by adsorbent is the best in acidic condition but at very low $\mathrm{pH}$, the dye molecules compete with the $\mathrm{H}^{+}$ions over the active sites on the adsorbent as mentioned by Mohammad et al. [57]. However, the scenario is not noticeable by the study conducted by Mohammad et al. 2017 as shown in Fig. 3c [57]. This is because the small particle size of the coconut fronds remediated the competition and hence, the optimum $\mathrm{pH}$ for the adsorption is 1 [59]. Figure $3 d$ infers that the adsorption isotherm for Malachite Green dye occurs at specific homogeneous sites on the coconut fronds because the $\mathrm{R} 2$ value obtained equals to 1 . The maximum adsorption capacity of Malachite Green is $18.98 \mathrm{mg} / \mathrm{g}$.

\section{Coconut fiber}

Coconut fiber also known as coconut grate residue is the by-product of coconut gratings. The milked coconut gratings are obtained from the fresh coconut endosperm via wet processing for the production of virgin coconut oil [58]. Rani et al. (2017) treated the dry coconut fiber with acid followed by hexane at high pressure (CAH) for the adsorption of Congo Red [58]. The purpose of the acid treatment is to enhance the positive charge on the surface of coconut fiber for better entrapment of anionic dye. Likewise, addition of hexane dissolves the excess oil on the surface of the coconut fiber which could retard the interaction with the adsorbate. Congo Red as shown in Figure A5, Supporting Information attained the highest adsorption on the $\mathrm{CAH}$ at low $\mathrm{pH}(\mathrm{pH}=3)$. At low $\mathrm{pH}$, the concentration of $\mathrm{H}^{+}$ions are 

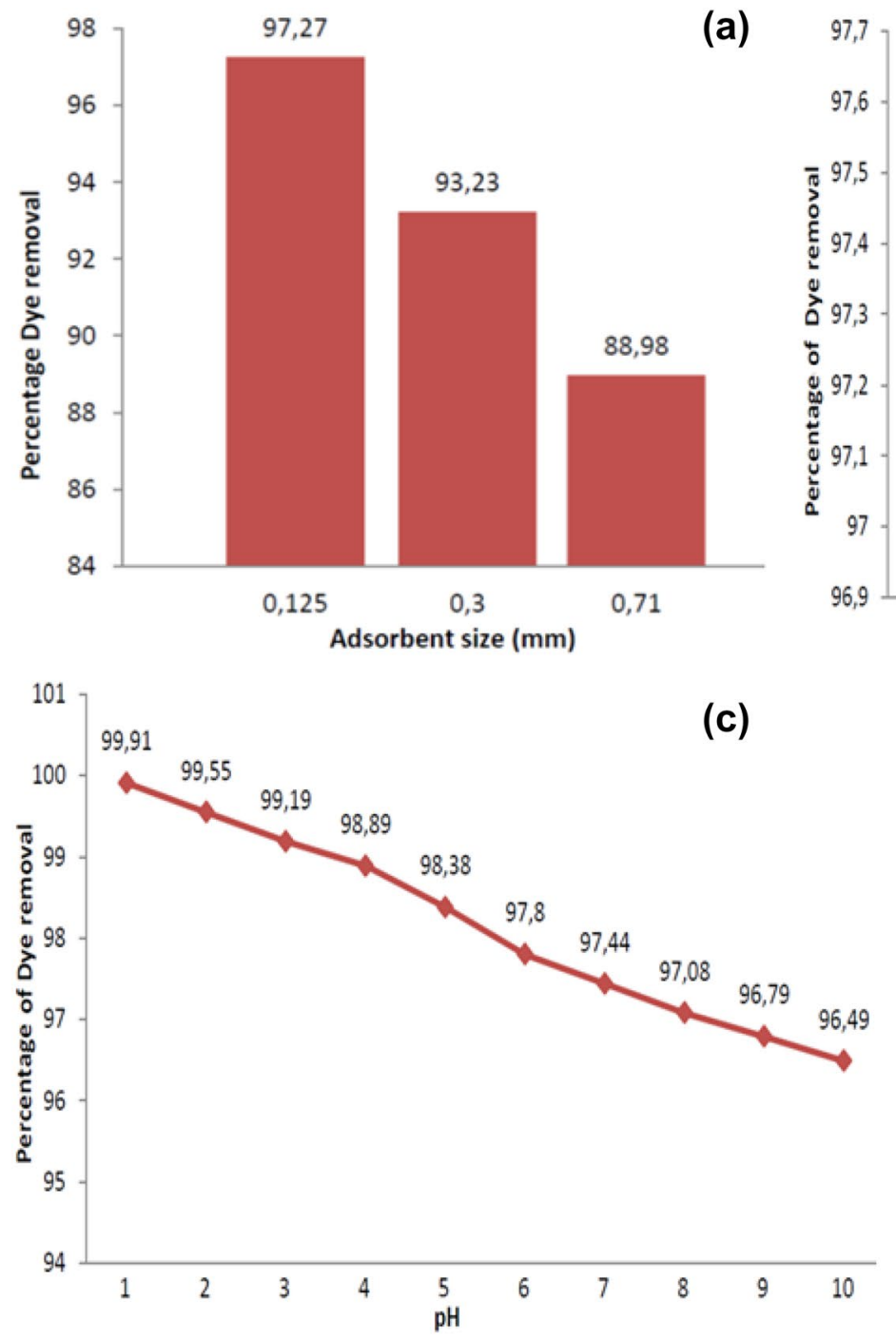

(b)

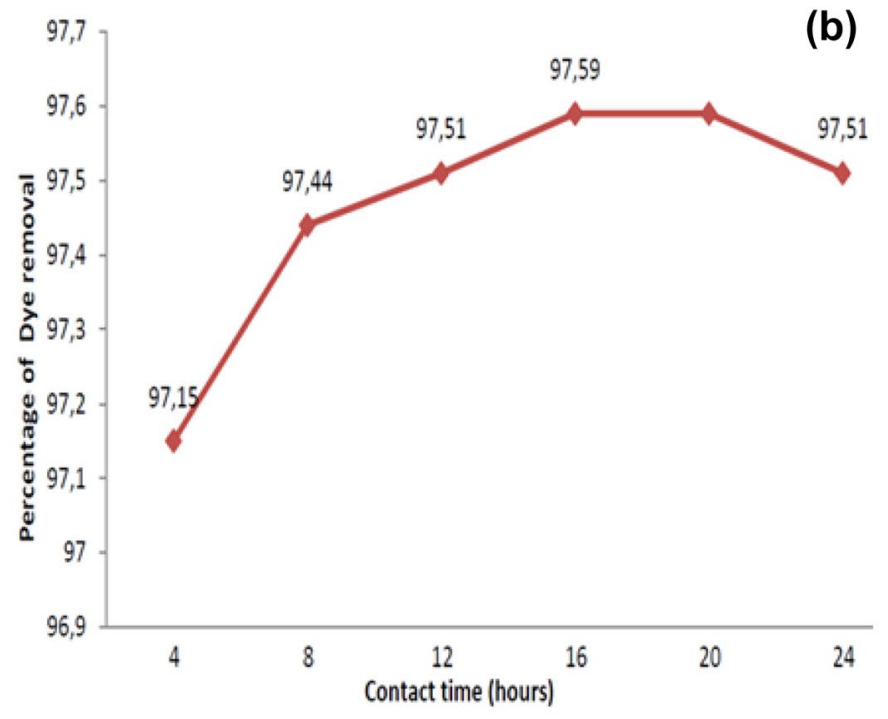

(d)

Fig. 3 Characteristics of coconut frond in adsorption of Malachite Green (a) adsorbent size (b) contact time (c) initial pH and (d) adsorption equilibrium isotherm [57]

high, hence it caters sites for Congo Red, an anionic dye, for electrostatic attraction [60].

\subsection{Adsorption kinetics}

\subsubsection{Freundlich}

The adsorption process fitted Freundlich isotherm and pseudo-second order kinetic models. Freundlich isotherm model states that there is exponential distribution of active sites on adsorbent for the heterogeneous sorption of adsorbate. The Freundlich isotherm model can be written as follows [61]:

$q_{e}=K_{F} C_{e}^{\frac{1}{n}}$ where $q_{e}$ is the amount of adsorbate per unit mass of adsorbent at equilibrium $(\mathrm{mg} / \mathrm{g}), K_{F}$ is the adsorption capacity constant $(\mathrm{L} / \mathrm{g}), C_{e}$ is the concentration of the adsorbate at equilibrium $(\mathrm{mg} / \mathrm{L}), n$ is the heterogeneity factor and $\frac{1}{n}$ is the adsorption intensity. The Freundlich isotherm model is rearranged for plotting the graph and it can be written as follows:

$\log _{10} q_{e}=\frac{1}{n} \log _{10} C_{e}+\log _{10} K_{F}$

When a graph of $\log _{10} q_{e}$ is plotted against $\log _{10} C_{e^{\prime}}$ a linear graph is acquired with regression linear coefficient, $R^{2}$, close to unity. The $n$ and $K_{F}$ are obtained from the gradient and intercept of the graph. Both the gradient and intercept of the graph represent the values for $\frac{1}{n}$ and $\log _{10} K_{F}$, respectively. If the value of $\frac{1}{n}$ falls in between 0 and 1 , it signifies 
the easiness of the adsorption process [62]. The maximum adsorption capacity, $K_{F}, \frac{1}{n}$ and $R^{2}$ values for the adsorption of Congo Red by CAH are $128.94 \mathrm{mg} / \mathrm{g}, 1.23 \mathrm{~L} / \mathrm{mg}, 0.6289$ and 0.99 , respectively. The outstanding performance of $\mathrm{CAH}$ is fully supported by the $k_{2}$, actual $q_{e}$ and $\mathrm{R}^{2}$ values of $0.20 \mathrm{~g} /$ $\mathrm{mg} \mathrm{min}, 4.93 \mathrm{mg} / \mathrm{g}$ and 0.99 , respectively obtained from the pseudo-second order adsorption kinetic.

\subsubsection{Brauner-Emmet-Teller (BET)}

It is worth mentioning that the adsorption of Congo Red by CAH obeyed Brauner-Emmet-Teller (BET) isotherm. The BET isotherm model states that the gaseous adsorbate molecules move randomly on the adsorbent sites (i.e. empty, covered with monolayer or multiple layers adsorbate molecules) instead of the surface of the adsorbent. The BET isotherm model can be written as follows [63]:

$\frac{C_{e}}{\left(C_{s}-C_{e}\right) q_{e}}=\frac{1}{K_{B} q_{s}}+\frac{\left(K_{B}-1\right)}{K_{B} q_{s}} \times \frac{C_{e}}{C_{s}}$

where $q_{s}$ is the amount of adsorbate per unit mass of adsorbent when all layers are saturated $(\mathrm{mg} / \mathrm{g}), K_{B}$ is the BET adsorption constant (a function of the energy of adsorption and temperature) and $C_{s}$ is the concentration of adsorbate when all layers are saturated $(\mathrm{mg} / \mathrm{L})$. When a graph of $\frac{C_{e}}{\left(C_{s}-C_{e}\right) q_{e}}$ is plotted against $\frac{C_{e}}{C_{s}}$, a linear graph is acquired with regression linear coefficient, $R^{2}$, close to unity. The $K_{B}$ and $q_{S}$ are obtained from the gradient and intercept of the graph. Both the gradient and intercept of the graph represent the values for $\frac{\left(K_{B}-1\right)}{K_{B} q_{s}}$ and $\frac{1}{K_{B} q_{s}}$, respectively. The $K_{B}, q_{S}$ and $\mathrm{R}^{2}$ values obtained by the adsorption of Congo Red by CAH are 12.00, $92.59 \mathrm{mg} / \mathrm{g}$ and 0.97 , respectively.

\subsection{Thermodynamics study}

Thermodynamic analysis is conducted to evaluate the spontaneity, type and the effect of temperature on the biosorption process. The criteria of the adsorption can be determined by the equations as follow:

$\Delta G=-R T \ln K$

$K=\frac{q_{e}}{C_{e}}$

$\Delta G=\Delta H^{\circ}-T \Delta S^{\circ}$

where $\Delta G$ is the Gibbs free energy at non-standard condition $(\mathrm{J} / \mathrm{mol}), R$ is the molar universal gas constant $(8.3145 \mathrm{~J} /$ $\mathrm{mol} \mathrm{K),} T$ is the absolute temperature, $K$ is the equilibrium constant, $q_{e}$ is the maximum adsorption capacity at equilibrium $(\mathrm{mg} / \mathrm{g}), C_{e}$ is the concentration of adsorbate remaining in the solution at equilibrium $(\mathrm{mg} / \mathrm{L}), \Delta H^{\circ}$ is the standard enthalpy change $(\mathrm{J} / \mathrm{mol})$ and $\Delta S^{\circ}$ is the standard entropy change $(\mathrm{J} / \mathrm{mol} \mathrm{K})$.

The adsorption process of Congo Red by $\mathrm{CAH}$ is nonspontaneous because the $\Delta G$ at $300 \mathrm{~K}$ is a positive value $(16.51 \mathrm{~kJ} / \mathrm{mol})$. The result is in well agreement with the negative value of entropy change $\left(\Delta S^{\circ}=-0.12 \mathrm{~kJ} / \mathrm{mol} \mathrm{K}\right)$ owing to the decreased disorder at the solid/liquid interface. The adsorption is a physical adsorption because the $\Delta H^{\circ}$ values obtained $\mathrm{CAH}$ is $-19.39 \mathrm{~kJ} / \mathrm{mol}$ (negative, exothermic).

\section{Fallen coconut leaves}

Fallen coconut leaves are agricultural wastes largely available in Malaysia. The performance in adsorption of Methylene Blue by untreated fallen coconut leaves (UCL) was compared with fallen coconut leaves impregnated with $\mathrm{H}_{3} \mathrm{PO}_{4}$ followed by microwave pyrolysis (PCL). Table 2 summarizes the results for the adsorption of Methylene Blue by fallen coconut leaves (untreated and treated). The performance of $\mathrm{PCL}$ improved by $122.52 \%$ because the maximum adsorption capacity increased to $250 \mathrm{mg} / \mathrm{g}$ from $112.35 \mathrm{mg} / \mathrm{g}$. However, the performance of coconut leaves impregnated with $\mathrm{H}_{3} \mathrm{PO}_{4}$ followed by carbonization at $700^{\circ} \mathrm{C}$ (HACL) increased by $217.88 \%$ to $357.14 \mathrm{mg} / \mathrm{g}$ compared to UCL. Both PCL and HACL obtained high maximum adsorption capacity of $250 \mathrm{mg} / \mathrm{g}$ and $357.14 \mathrm{mg} / \mathrm{g}$, respectively. The results are congruent to the negative values of $\Delta \mathrm{G}$ at $300 \mathrm{~K}$ that are $-5.95 \mathrm{~kJ} / \mathrm{mol}$ and $-55.11 \mathrm{~kJ} / \mathrm{mol}$ by $\mathrm{PCL}$ and $\mathrm{HACL}$, respectively which indicates spontaneity of the adsorption process. Moreover, the positive values of standard entropy change obtained by $\mathrm{PCL}$ and $\mathrm{HACL}$ are $0.3750 \mathrm{~kJ} / \mathrm{mol}$ and $0.1096 \mathrm{~kJ} / \mathrm{mol}$, respectively indicating that the arrangement of atoms in the adsorption process are highly disorder. The adsorption of Methylene Blue by $P C L$ is exothermic $\left(\Delta H^{\circ}=-107.70 \mathrm{~kJ} / \mathrm{mol}\right)$ whereas the adsorption of Methylene Blue by HACL is endothermic $\left(\Delta H^{\circ}=+21.91 \mathrm{~kJ} / \mathrm{mol}\right)$. Therefore, the adsorption of Methylene Blue by $\mathrm{HACL}$ requires heating to amplify the movement of atoms. Nonetheless, an attempt to impregnate coconut leaves with $\mathrm{FeCl}_{3}$ followed by carbonization at $700{ }^{\circ} \mathrm{C}(\mathrm{FACL})$ requires additional improvement because it's adsorption capacity dropped by $41.26 \%$ to $66 \mathrm{mg} / \mathrm{g}$ compared to UCL.

The optimum $\mathrm{pH}$ for the adsorption of Methylene Blue by $\mathrm{UCL}$ is 8.65 . At this $\mathrm{pH}$, the concentration of hydroxide ions, $\mathrm{OH}^{-}$is slightly higher than hydroxonium ions, $\mathrm{H}_{3} \mathrm{O}^{+}$. It provides more active sites for the adsorption of cationic dyes through electrostatic force. The optimum $\mathrm{pH}$ for the adsorption of Methylene Blue depressed to the $\mathrm{pH}$ range from 5 to 6 for PCL, HACL and FACL. It was revealed that 
the entrapment of dye molecules into the pore of the $\mathrm{PCL}$ and $\mathrm{HACL}$ strengthened the adsorption process at $\mathrm{pH} 5.60$ apart from electrostatic force [68]. This is because the small ionic size of $\mathrm{H}^{+}$ions impregnated on the surface of fallen coconut leaves created a network for better entrapment of dye molecules. However, FACL adsorbent encountered a drop in adsorption capacity at $\mathrm{pH}=5.60$ because the impregnation of large ionic size of $\mathrm{Fe}^{3+}$ ions on the surface of fallen coconut leaves creating small pore network. The presence of steric hindrance in the network hinders the entrapment of dye molecules [69].

All the adsorption process obeyed Langmuir equilibrium isotherm. The linear regression values are close to unity and subsequently the Langmuir constant values, $\mathrm{K}_{\mathrm{L}}$, increase with the maximum adsorption capacity values.
Also, the adsorption kinetics fitted pseudo-second order. It is worth noting that the adsorption of Methylene Blue by PCL portrayed Weber-Morris intraparticle diffusion model. The model was developed in 1962 for the analysis of the adsorption kinetics. The model can be written as follows [70]:

$q_{t}=K_{i d} t^{\frac{1}{2}}+C$

where $q_{t}$ is the adsorption capacity at any time $(\mathrm{mg} / \mathrm{g}), K_{i d}$ is the intraparticle diffusion rate constant $\left(\mathrm{mg} / \mathrm{gmin}^{1} 1 / 2\right), t$ is the time taken for the adsorption process $(\mathrm{min}$ ) and $C$ is a constant for the any experiment $(\mathrm{mg} / \mathrm{g})$. When a graph of $q_{t}$ is plotted against $t^{\frac{1}{2}}$, a linear graph is obtained with regression linear coefficient, $R^{2}$, close to unity. The gradient
Fig. 4 The Weber-Morris intraparticle diffusion model for the adsorption of Methylene Blue by PCL [65]
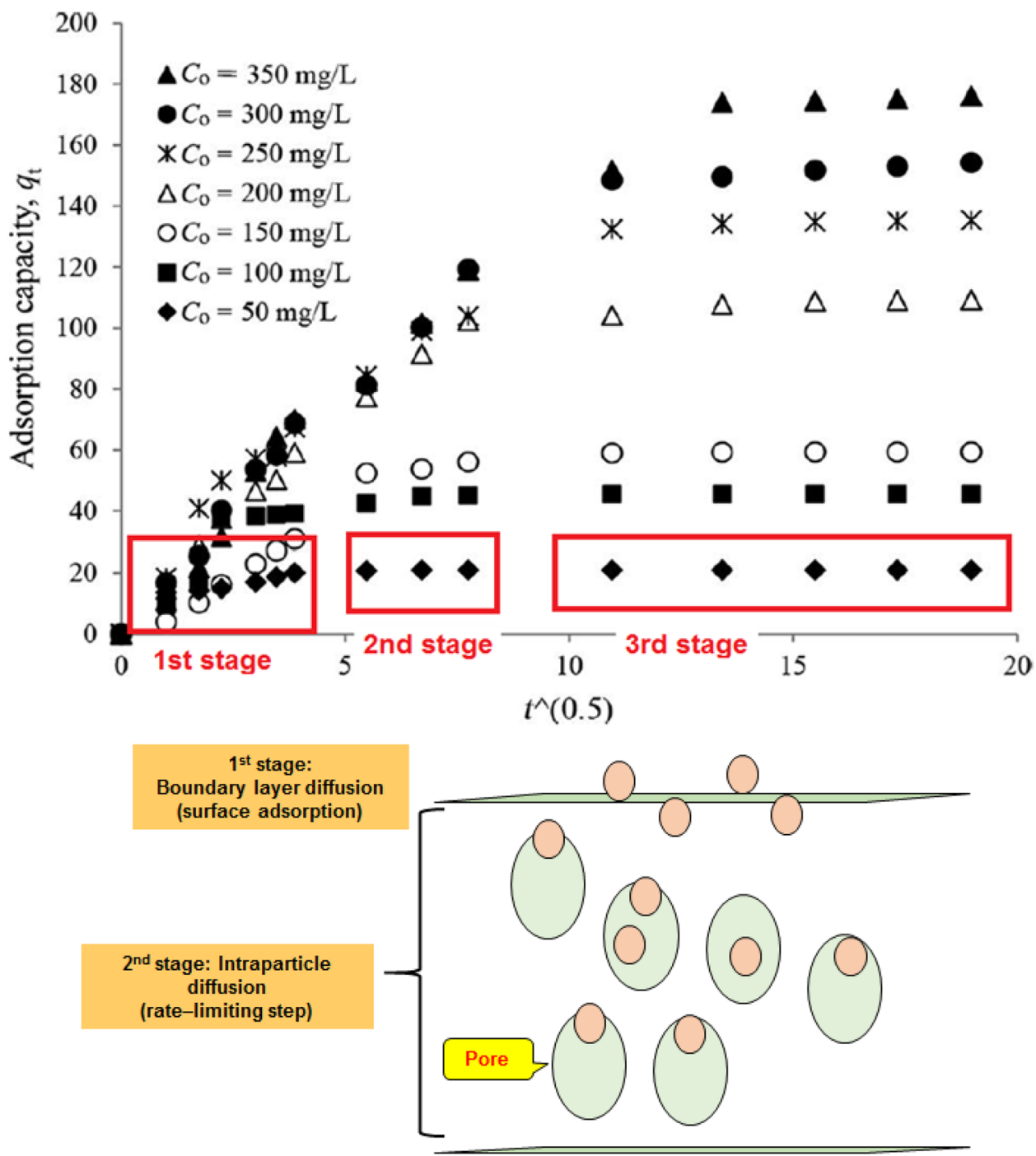

Adsorbent

Solute 
of the graph reveals the intraparticle diffusion rate constant, $K_{i d}$. Figure 4 represents the Weber-Morris intraparticle diffusion model for the adsorption of Methylene Blue by PCL [65].

The adsorption of Methylene Blue by $\mathrm{PCL}$ is divided into three stages because when a graph of $q_{t}$ is plotted against $t^{\frac{1}{2}}$, multiple linearity is obtained. The first linearity (first stage) represents the adsorption of Methylene Blue at the boundary layer. The second linearity (second stage) describes the diffusion of Methylene Blue into the pore of the adsorbent. The linear graph plotted at this stage is used to calculate the intraparticle diffusion rate constant, $K_{i d}\left(2.3 \mathrm{mg} / \mathrm{gmin}^{1} / 2\right.$ at $\left.50 \mathrm{mg} / \mathrm{L}\right)$. The intraparticle diffusion will be extended until the adsorbent attained equilibrium (adsorbent is saturated with adsorbate) which is also known as third stage.

\section{Babassu coconut}

The activated carbon prepared by using babassu coconut $(A C B C)$ obtained from Tobasa Bioindustrial Babaçu S.A company was used as received. It has been used to adsorb tartrazine yellow dye (anionic) which is also known as trisodium (4E)-5-oxo-1-(4-sulfonatophenyl)-4-[(4sulfonatophenyl)hydrazono]-3-pyrazolecarboxylate as shown in Figure A6, Supporting Information. The adsorption process in an endothermic reaction because the $\Delta \mathrm{H}^{\circ}$ value is $39.06 \mathrm{~kJ} / \mathrm{mol}$. The suitable $\mathrm{pH}$ for the adsorption of tartrazine is 3 , which is in well agreement with the theory. Generally, an anionic (negatively charged) dye constructs electrostatic attraction with $\mathrm{H}_{3} \mathrm{O}^{+}$ions at acidic condition. It requires $12 \mathrm{~h}$ contact time to achieve equilibrium. ACBC is capable in adsorbing $31.10 \mathrm{mg} / \mathrm{g}$ of tartrazine at $298 \mathrm{~K}$ owing to its spontaneity $\left(\Delta \mathrm{G}^{\circ}=-3.5878 \mathrm{~kJ} / \mathrm{mol}\right)$ and highly disorder arrangement of atoms $\left(\Delta S^{\circ}=146.27 \mathrm{~J} / \mathrm{mol} \mathrm{K}\right)$. The adsorption of tartrazine by ACBC met Freundlich isotherm and it is highly favorable because the $R^{2}$ and $n$ values are 0.9796 and 1.3473 , respectively as well as $K_{F}$ equals to 2.84 $\mathrm{L} / \mathrm{mg}$. Likewise, the adsorption of tartrazine by ACBC comply with the pseudo-second order because the $\mathrm{q}_{\mathrm{e}}$ theoretical $(3.80 \mathrm{mg} / \mathrm{g})$ is approximate to the $\mathrm{q}_{\mathrm{e}}$ actual $(3.66 \mathrm{mg} / \mathrm{g})$. Also, the $R^{2}$ are close to unity (0.9646) along with $\mathrm{k}_{2}$ equals to $0.0039 \mathrm{~g} / \mathrm{mg}$ min, respectively.

\section{Green coconut mesocarp}

Green coconut mesocarp is a young coconut shell which is not treated and was used to adsorp Remazol Golden Yellow RNL-150\% (RGY), anionic dye by Nascimento et al. (2016) [71]. The chemical structure of Remazol Golden Yellow RNL-150\% (RGY) is shown in Figure A7, Supporting
Information. The dye unites harmoniously with protons on the adsorbent via electrostatic synergistic in acidic condition. As such, the optimum $\mathrm{pH}$ for the adsorption process is 2 and the green coconut mesocarp successfully adsorbed $9.6 \mathrm{mg} / \mathrm{g}$ at $298 \mathrm{~K}$. The data for adsorption process fits Freundlich isotherm with $R^{2}$ value of 0.995 . The adsorption process is favored because the $\mathrm{n}$ and $\mathrm{K}_{\mathrm{F}}$ are equals to 2.3 and $1.8 \mathrm{~L} / \mathrm{mg}$. The analyzed data revealed that the rate-determining step satisfied pseudo-second order with $R^{2}$ value equals to 0.976 . In fact, both the theoretical and actual qe are identical $(7.7 \mathrm{mg} / \mathrm{g})$ along with $\mathrm{k}_{2}$ equals to $0.031 \mathrm{~g} / \mathrm{mg} \mathrm{min}$.

\section{Coconut coir dust}

Coconut coir dust (brown, spongy particle) is produced after the extraction of fibre from the coconut husk. It composed mainly lignins and tannins apart from cellulose, pentosane and furfural. It has been explored for the media for containerized crop production instead of waste materials. In the studies carried out, (Etim et al., 2016) did not modify the coconut coir dust whereas (Ikhazuangbe et al., 2017) carbonized and activated the coconut fiber at $400{ }^{\circ} \mathrm{C}$ and $800^{\circ} \mathrm{C}$, respectively $[72,73]$. The performances of the unmodified and modified coconut coir dust towards Methylene Blue and Erythrosine, respectively are shown in Table 3.

The optimum $\mathrm{pH}$ for the adsorption of Methylene Blue is 6. The adsorption of Methylene Blue by coconut coir dust is not suitable for too low $\mathrm{pH}$ owing to the competition between the $\mathrm{H}^{+}$ions and $\mathrm{NH}_{4}^{+}$ions for the active sites. The result obtained is in well agreement with the adsorption of Methylene Blue by activated carbon by coconut leaves impregnated with $\mathrm{H}_{3} \mathrm{PO}_{4}$ via microwave pyrolysis and carbonization at $700{ }^{\circ} \mathrm{C}[65,66]$. Generally, the amount of adsorbate increases with the increasing dosage of adsorbent at constant initial concentration [74]. As the amount of adsorbent increases, the surface area increases that led to the elevation of adsorption sites until it reaches equilibrium. At higher dosage of adsorbent, the percentage removal of dyes becomes constant owing to overlapping of active sites [75].

Figure 5 illustrates the relationship between the dosage of adsorbent and the adsorption capacity at $35^{\circ} \mathrm{C}$ for $40 \mathrm{~min}$ [76]. Based on Fig. 5, at 20, 30, 40 and $60 \mathrm{mg} / \mathrm{L}$ Congo red, it requires 500, 600, 600 and $900 \mathrm{mg}$ of coir pith carbon, respectively to attain equilibrium. Based on the result, every $1 \mathrm{~g}$ of coconut coir dust is able to adsorb $29.50 \mathrm{mg}$ of Methylene Blue and the adsorption process suits Temkin Model. Figure 6 depicts the Temkin isotherm model for the adsorption of Methylene Blue by coconut coir dust [72]. Temkin model states that the strength of 
Table 3 Performances of unmodified and modified coconut coir dust towards Methylene Blue and

Erythrosine, respectively

\begin{tabular}{lll}
\hline Characteristics & Adsorbents & \\
\cline { 2 - 3 } & Coconut coir dust [72] & Coconut fiber [73] \\
\hline Adsorbate & Methylene Blue & Erythrosine or Acid Red \\
$\mathrm{pH}$ & 6 & $\mathrm{NIL}$ \\
$\mathrm{Adsorption}$ equilibrium isotherm at 303 K & Temkin model isotherm & Freundlich isotherm \\
$\mathrm{K}_{\mathrm{T}}$ & 14.75 & $\mathrm{KF}(\mathrm{L} / \mathrm{mg}) 0.8872$ \\
$\mathrm{~B}_{1}$ & 4.43 & $\mathrm{n} 3.50$ \\
$\mathrm{R}^{2}$ & 0.99 & $\mathrm{R} 20.8800$ \\
Adsorption kinetics at 50 mg/L & Pseudo-second order & \\
$\mathrm{k}_{2}$ (g/mg min) & 0.76 & 0.0465 \\
$\mathrm{q}_{\mathrm{e}}$ theoretical (mg/g) & 11.90 & 1.7036 \\
$\mathrm{q}_{\mathrm{e}}$ actual (mg/g) & 11.84 & $\mathrm{NIL}$ \\
$\mathrm{R}^{2}$ & 1.00 & 0.9970 \\
Thermodynamics study & & \\
$\Delta \mathrm{H}^{\circ}$ & $17.87 \mathrm{~kJ} / \mathrm{mol}$ (Endothermic) & $28.73 \mathrm{~kJ} / \mathrm{mol}$ (Endothermic) \\
$\Delta \mathrm{S}^{\circ}$ & $51.10 \mathrm{~kJ} / \mathrm{mol} \mathrm{K}$ & $0.09445 \mathrm{~kJ} / \mathrm{mol} \mathrm{K}$ \\
$\Delta \mathrm{G}$ at 303 K & $-9.69 \mathrm{~kJ} / \mathrm{mol}$ (Spontaneous) & $-0.10 \mathrm{~kJ} / \mathrm{mol}$ (Spontaneous)
\end{tabular}

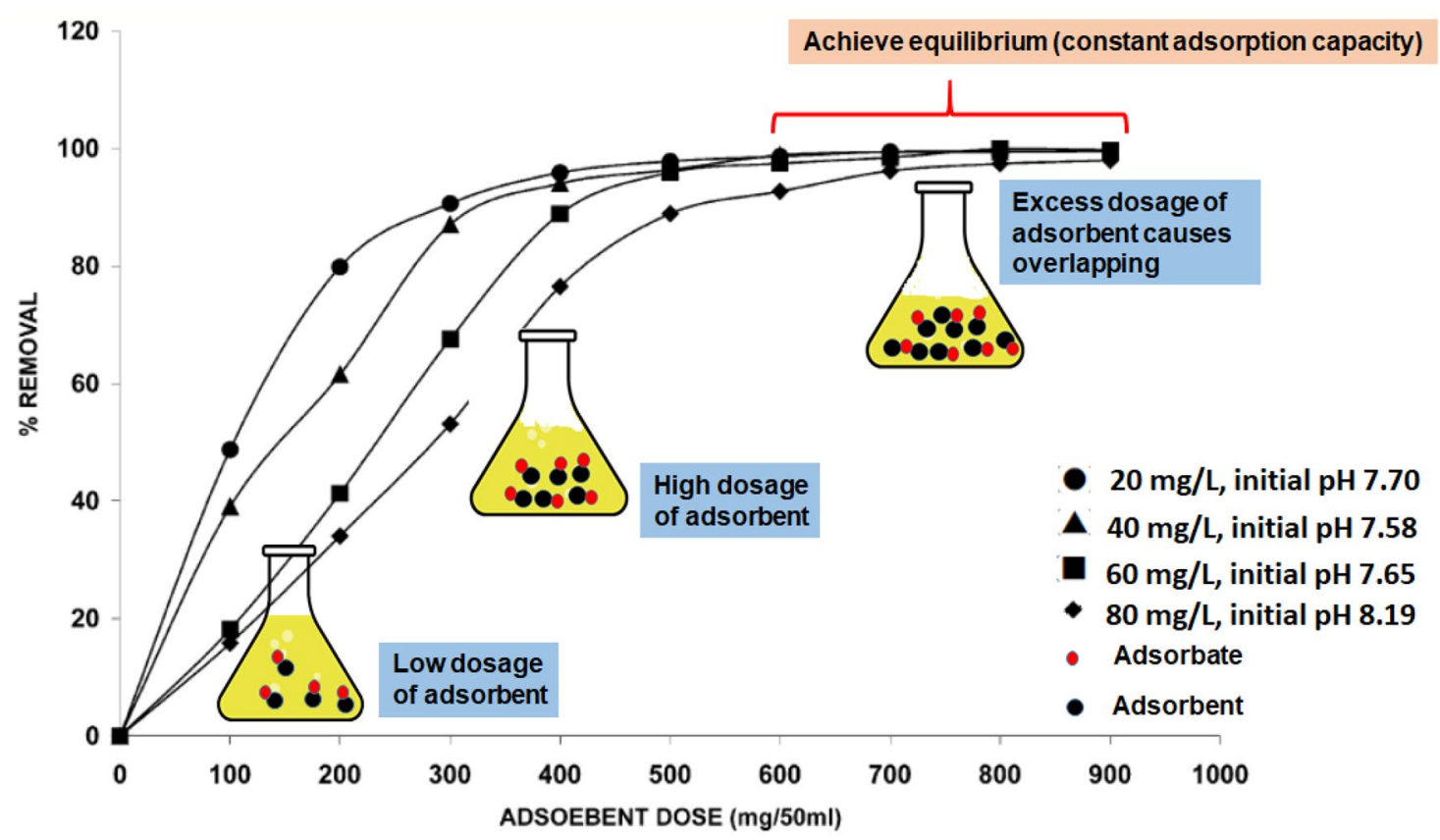

Fig. 5 The relationship between the dosage of adsorbent and the adsorption capacity at $35^{\circ} \mathrm{C}$ for $40 \mathrm{~min}$ [76]

the interaction between adsorbent and adsorbate (gaseous physical state) is inversely proportionate to the heat of adsorption. The model can be written as follows [40]:

$q_{e}=\frac{R T}{b} \ln \left(A_{T} C_{e}\right)$

where $q_{e}$ is the amount of adsorbate per unit mass of adsorbent $(\mathrm{mg} / \mathrm{g}), R$ is the universal gas constant $(\mathrm{J} /$ $\mathrm{mol} \mathrm{K),} T$ is the absolute temperature (K), $A_{T}$ is the Temkin equilibrium binding constant $(\mathrm{L} / \mathrm{mg}), b$ is the Temkin isotherm constant and $C_{e}$ is the equilibrium concentration of adsorbate $(\mathrm{mg} / \mathrm{L})$. The Temkin isotherm model is rearranged for plotting the graph and it can be written as follows:

$q_{e}=\frac{R T}{b} \ln C_{e}+\frac{R T}{b} \ln A_{T}$ 


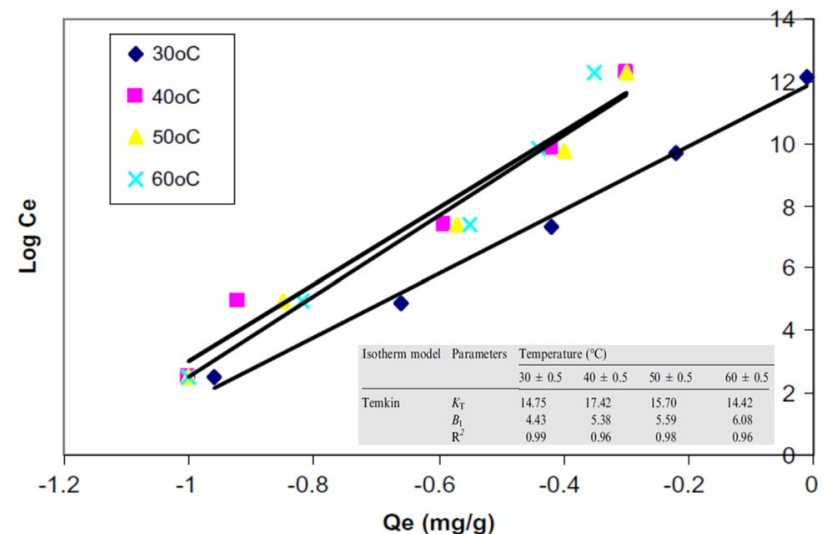

Fig. 6 Temkin isotherm model for the adsorption of Methylene Blue by coconut coir dust [72]

When a graph of $\ln C_{e}$ is plotted against $q_{e^{\prime}}$ a linear graph is acquired with regression linear coefficient, $R^{2}$, close to unity. The $b$ and $A_{T}$ are obtained from the gradient and intercept of the graph. Both the gradient and intercept of the graph represent the values for $\frac{R_{T}}{b}$ (related to the heat of adsorption) and $\frac{R_{T}}{b} \ln A_{T}$, respectively. The heat of adsorption $\left(\frac{R_{T}}{b}\right)$ values increase with absolute temperature and thus the adsorption process is endothermic as supported by the $\Delta \mathrm{H}^{\circ}$ value of $17.87 \mathrm{~kJ} / \mathrm{mol}$. The $A_{T}$ values increase with temperature until it reaches saturation. The $A_{T}$ values increase to $17.42 \mathrm{~L} / \mathrm{mg}$ at $313 \mathrm{~K}$ from $14.72 \mathrm{~L} / \mathrm{mg}$ at $303 \mathrm{~K}$. Following this, the amount of Methylene Blue adsorbed per $\mathrm{mg}$ of coconut coir dust reduced to $15.70 \mathrm{~L}$ and 14.42 $\mathrm{L}$ at $323 \mathrm{~K}$ and $333 \mathrm{~K}$, respectively. The adsorption process is spontaneous and favored because the $\Delta \mathrm{G}$ at $303 \mathrm{~K}$ equals to $-9.69 \mathrm{~kJ} / \mathrm{mol}$ and the standard entropy change is $51.10 \mathrm{~kJ} / \mathrm{mol} \mathrm{K}$. Likewise, the adsorption of Erythrosine by modified coconut fiber is endothermic $\left(\Delta \mathrm{H}^{\circ}=28.73 \mathrm{~kJ} /\right.$ $\mathrm{mol})$ and spontaneous $(\Delta \mathrm{G}=-0.10 \mathrm{~kJ} / \mathrm{mol})$ along with $\Delta \mathrm{S}^{\circ}=0.09445 \mathrm{~kJ} / \mathrm{mol} \mathrm{K}$. Both adsorption processes match to pseudo-second order which is in line with the $R^{2}$ value of 1.00. The adsorption of Methylene Blue by unmodified coconut coir dust shown more prominent results than the adsorption of Erythrosine by modified coconut fiber. This is because the qe theoretical $(11.90 \mathrm{mg} / \mathrm{g})$ and $\mathrm{k} 2(0.76 \mathrm{~g} /$ $\mathrm{mg} \mathrm{min}$ ) values of unmodified coconut coir dust are higher than qe theoretical $(1.7036 \mathrm{mg} / \mathrm{g})$ and $\mathrm{k}_{2}(0.0465 \mathrm{~g} /$ $\mathrm{mg}$ min) values of modified coconut fiber. In fact, the $\mathrm{q}_{\mathrm{e}}$ experimental value $(11.84 \mathrm{mg} / \mathrm{g})$ differ from the $\mathrm{q}_{\mathrm{e}}$ theoretical value $(11.90 \mathrm{mg} / \mathrm{g})$ by $0.504 \%$ for the unmodified coconut coir dust.

On the contrary, Freundlich isotherm model was obeyed by the adsorption of Erythrosine by modified coconut fiber owing to it's close to unity $R^{2}$ value of 0.8800 . The $n$ and $K_{F}$ values obtained are 3.50 and $0.8872 \mathrm{~L} / \mathrm{mg}$, respectively.

\section{SN Applied Sciences}

\section{Conclusions}

There are four important parameters $(\mathrm{pH}$, contact time, amount of adsorbent and initial concentration of adsorbate) for the removal of dyes via adsorption technique. Generally, the adsorption of anionic dye is highly favored at low $\mathrm{pH}$ and in contrast, the adsorption of cationic dye is favored at high $\mathrm{pH}$. The rate of adsorption of dye molecules on the coconut based adsorbents obeyed pseudo-second order, Elovich chemisorption and Weber-Morris intraparticle diffusion model. These coconut-based adsorbents fitted the Langmuir, Fritz-Schlunder, Langmuir type-2, Freundlich, Brauner-Emmet-Teller (BET) and Temkin isotherm models. In the thermodynamic studies, both the $\Delta G$ and $\Delta \mathrm{H}$ values determine the spontaneity and the type of a reaction. The positive value of $\Delta G$ signifies the nonspontaneous of the reaction and vice-versa. On the other hand, positive value of $\Delta \mathrm{H}$ indicates the reaction is endothermic and vice-versa.

Funding The authors declare that they have no known competing financial interests or personal relationships that could have appeared to influence the work reported in this paper.

\section{Compliance with ethical standards}

Conflict of interest The authors declare that they have no conflict of interest.

\section{References}

1. Pang YL, Abdullah AZ (2013) Current status of textile industry wastewater management and research progress in Malaysia: a review. Clean-Soil Air Water 41(8):751-764

2. Afroz R, Masud MM, Akhtar R, Duasa JB (2014) Water pollution: challenges and future direction for water resource management policies in Malaysia. Environ Urban ASIA 5(1):63-81

3. Afroz R, Rahman A (2017) Health impact of river water pollution in Malaysia. Int J Adv Appl Sci 4(5):78-85

4. Yagub MT, Sen TK, Afroze S, Ang HM (2014) Dye and its removal from aqueous solution by adsorption: a review. Adv Coll Interface Sci 209:172-184

5. Ngah WW, Teong L, Hanafiah M (2011) Adsorption of dyes and heavy metal ions by chitosan composites: a review. Carbohydr Polym 83(4):1446-1456

6. Shindy $\mathrm{H}$ (2016) Basics in colors, dyes and pigments chemistry: a review. Chem Int 2(29):2016

7. Rai HS, Bhattacharyya MS, Singh J, Bansal T, Vats $P$, Banerjee $U$ (2005) Removal of dyes from the effluent of textile and dyestuff manufacturing industry: a review of emerging techniques with reference to biological treatment. Crit Rev Environ Sci Technol 35(3):219-238

8. Nidheesh PV, Gandhimathi R, Ramesh ST (2013) Degradation of dyes from aqueous solution by Fenton processes: a review. Environ Sci Pollut Res 20(4):2099-2132 
9. Mirjalili M, Nazarpoor K, Karimi L (2011) Eco-friendly dyeing of wool using natural dye from weld as co-partner with synthetic dye. J Clean Prod 19(9-10):1045-1051

10. Pandey $A$, Singh $P$, lyengar $L$ (2007) Bacterial decolorization and degradation of azo dyes. Int Biodeterior Biodegrad 59(2):73-84

11. Phalakornkule $C$, Polgumhang $S$, Tongdaung W, Karakat $B$, Nuyut $T$ (2010) Electrocoagulation of blue reactive, red disperse and mixed dyes, and application in treating textile effluent. J Environ Manage 91(4):918-926

12. Kaykhaii M, Sasani M, Marghzari S (2018) Removal of dyes from the environment by adsorption process. Chem Mater Eng 6(2):31-35

13. Robinson T, McMullan G, Marchant R, Nigam P (2001) Remediation of dyes in textile effluent: a critical review on current treatment technologies with a proposed alternative. Biores Technol 77(3):247-255

14. Kiernan J (2001) Classification and naming of dyes, stains and fluorochromes. Biotech Histochem 76(5-6):261-278

15. Kim H, Kang S-O, Park S, Park HS (2015) Adsorption isotherms and kinetics of cationic and anionic dyes on three-dimensional reduced graphene oxide macrostructure. J Ind Eng Chem 21:1191-1196

16. Raha S, Quazi N, Ivanov I, Bhattacharya S (2012) Dye/Clay intercalated nanopigments using commercially available non-ionic dye. Dyes Pigm 93(1-3):1512-1518

17. Carneiro PA, Umbuzeiro GA, Oliveira DP, Zanoni MVB (2010) Assessment of water contamination caused by a mutagenic textile effluent/dyehouse effluent bearing disperse dyes. J Hazard Mater 174(1-3):694-699

18. Elmoubarki R, Mahjoubi F, Tounsadi $\mathrm{H}$, Moustadraf J, Abdennouri M, Zouhri A, Albani A, Barka N (2015) Adsorption of textile dyes on raw and decanted Moroccan clays: kinetics, equilibrium and thermodynamics. Water Resour Ind 9:16-29

19. Ghaly A, Ananthashankar R, Alhattab M, Ramakrishnan V (2014) Production, characterization and treatment of textile effluents: a critical review. J Chem Eng Process Technol 5(1):1-19

20. Forgacs E, Cserhati T, Oros G (2004) Removal of synthetic dyes from wastewaters: a review. Environ Int 30(7):953-971

21. Gunatilake $S$ (2015) Methods of removing heavy metals from industrial wastewater. Methods 1(1):14

22. Crini G, Lichtfouse E (2019) Advantages and disadvantages of techniques used for wastewater treatment. Environ Chem Lett 17(1):145-155

23. Kamaz M, Rocha P, Sengupta A, Qian X, Wickramasinghe RS (2018) Efficient removal of chemically toxic dyes using microorganism from activated sludge: understanding sorption mechanism, kinetics, and associated thermodynamics. Sep Sci Technol 53(11):1760-1776

24. El-Hosiny Fl, Abdel-Khalek MA, Selim KA, Osama I (2018) Physicochemical study of dye removal using electro-coagulation-flotation process. Physicochem Probl Miner Process 54(2):321-333

25. Chaari I, Fakhfakh E, Medhioub M, Jamoussi F (2018) Comparative study on adsorption of cationic and anionic dyes by smectite rich natural clays. J Mol Struct 1179:672-677

26. Dos Santos AB, Cervantes FJ, Van Lier JB (2007) Review paper on current technologies for decolourisation of textile wastewaters: perspectives for anaerobic biotechnology. Biores Technol 98(12):2369-2385

27. Zhang J, Yan X, Hu M, Hu X, Zhou M (2018) Adsorption of Congo red from aqueous solution using $\mathrm{ZnO}$-modified $\mathrm{SiO} 2$ nanospheres with rough surfaces. J Mol Liq 249:772-778

28. Chen H, Zheng Y, Cheng B, Yu J, Jiang C (2018) Chestnut husklike nickel cobaltite hollow microspheres for the adsorption of Congo red. J Alloy Compd 735:1041-1051

29. Burakova I, Burakov A, Tkachev A, Troshkina I, Veselova O, Babkin A, Aung WM, Ali I (2018) Kinetics of the adsorption of scandium and cerium ions in sulfuric acid solutions on a nanomodified activated carbon. J Mol Liq 253:277-283

30. Johari K, Saman N, Song ST, Chin CS, Kong H, Mat H (2016) Adsorption enhancement of elemental mercury by various surface modified coconut husk as eco-friendly low-cost adsorbents. Int Biodeterior Biodegrad 109:45-52

31. Sebastian A, Nangia A, Prasad M (2018) A green synthetic route to phenolics fabricated magnetite nanoparticles from coconut husk extract: implications to treat metal contaminated water and heavy metal stress in Oryza sativa L. J Clean Prod 174:355-366

32. Atheba P, Drogui P, Trokourey A (2018) Adsorption kinetics and thermodynamics study of butylparaben on activated carbon coconut based. J Encapsul Adsorpt Sci 8(02):39

33. Mohammed J, Nasri NS, Zaini MAA, Hamza UD, Ani FN (2015) Adsorption of benzene and toluene onto $\mathrm{KOH}$ activated coconut shell based carbon treated with NH3. Int Biodeterior Biodegrad 102:245-255

34. Njoku V, Islam MA, Asif M, Hameed B (2014) Preparation of mesoporous activated carbon from coconut frond for the adsorption of carbofuran insecticide. J Anal Appl Pyrol 110:172-180

35. Yue L, Xia Q, Wang L, Wang L, DaCosta H, Yang J, Hu X (2018) $\mathrm{CO} 2$ adsorption at nitrogen-doped carbons prepared by $\mathrm{K} 2 \mathrm{CO} 3$ activation of urea-modified coconut shell. J Colloid Interface Sci 511:259-267

36. Boopathy R, Karthikeyan S, Mandal AB, Sekaran G (2013) Adsorption of ammonium ion by coconut shell-activated carbon from aqueous solution: kinetic, isotherm, and thermodynamic studies. Environ Sci Pollut Res 20(1):533-542

37. Liu L, Ji M, Wang F (2018) Adsorption of nitrate onto $\mathrm{ZnCl2}$ modified coconut granular activated carbon: kinetics, characteristics, and adsorption dynamics. Adv Mater Sci Eng 2018:12

38. Talat M, Mohan S, Dixit V, Singh DK, Hasan SH, Srivastava ON (2018) Effective removal of fluoride from water by coconut husk activated carbon in fixed bed column: experimental and breakthrough curves analysis. Groundw Sustain Dev 7:48-55

39. Aljeboree AM, Alshirifi AN, Alkaim AF (2017) Kinetics and equilibrium study for the adsorption of textile dyes on coconut shell activated carbon. Arab J Chem 10:\$3381-\$3393

40. Ahmed M, Mohamed A (2017) An efficient adsorption of indigo carmine dye from aqueous solution on mesoporous $\mathrm{Mg} /$ Fe layered double hydroxide nanoparticles prepared by controlled sol-gel route. Chemosphere 174:280-288

41. Islam MS, Ang BC, Gharehkhani S, Afifi ABM (2016) Adsorption capability of activated carbon synthesized from coconut shell. Carbon Lett 20:1-9

42. Islam MA, Ahmed M, Khanday W, Asif M, Hameed B (2017) Mesoporous activated coconut shell-derived hydrochar prepared via hydrothermal carbonization- $\mathrm{NaOH}$ activation for Methylene Blue adsorption. J Environ Manage 203:237-244

43. Srisorrachatr S, Kri-arb P, Sukyang S, Jumruen C (2017) Removal of basic dyes from solution using coconut shell charcoal. Paper presented at the MATEC Web of conferences

44. Jóźwiak T, Filipkowska U, Bugajska P, Kalkowski T (2018) The use of coconut shells for the removal of dyes from aqueous solutions. J Ecol Eng 19(4):129-135

45. Ndifor-Angwafor N, Tiotsop IK, Tchuifon DT, Ngakou C (2017) Biosorption of amaranth red in aqueous solution onto treated and untreated lignocellulosic materials (pineapple peelings and coconut shells). J Mater Environ Sci 8(12):4199-4212

46. Talha MA, Goswami M, Giri B, Sharma A, Rai B, Singh R (2018) Bioremediation of Congo red dye in immobilized batch and continuous packed bed bioreactor by Brevibacillus parabrevis using coconut shell bio-char. Biores Technol 252:37-43 
47. Asfaram A, Ghaedi M, Ghezelbash GR, Pepe F (2017) Application of experimental design and derivative spectrophotometry methods in optimization and analysis of biosorption of binary mixtures of basic dyes from aqueous solutions. Ecotoxicol Environ Saf 139:219-227

48. Abdi S, Nasiri M, Mesbahi A, Khani M (2017) Investigation of uranium ( $\mathrm{VI})$ adsorption by polypyrrole. J Hazard Mater 332:132-139

49. Zhang B, Dong Z, Sun D, Wu T, Li Y (2017) Enhanced adsorption capacity of dyes by surfactant-modified layered double hydroxides from aqueous solution. J Ind Eng Chem 49:208-218

50. Sewu DD, Boakye P, Woo SH (2017) Highly efficient adsorption of cationic dye by biochar produced with Korean cabbage waste. Biores Technol 224:206-213

51. Putro JN, Santoso SP, Ismadji S, Ju Y-H (2017) Investigation of heavy metal adsorption in binary system by nanocrystalline cellulose-bentonite nanocomposite: improvement on extended Langmuir isotherm model. Microporous Mesoporous Mater 246:166-177

52. Rafati L, Ehrampoush M, Rafati A, Mokhtari M, Mahvi A (2018) Removal of ibuprofen from aqueous solution by functionalized strong nano-clay composite adsorbent: kinetic and equilibrium isotherm studies. Int J Environ Sci Technol 15(3):513-524

53. Narayanan N, Gupta S, Gajbhiye V, Manjaiah K (2017) Optimization of isotherm models for pesticide sorption on biopolymer-nanoclay composite by error analysis. Chemosphere 173:502-511

54. Khan TA, Nazir M, Ali I, Kumar A (2017) Removal of chromium (VI) from aqueous solution using guar gum-nano zinc oxide biocomposite adsorbent. Arab J Chem 10:S2388-S2398

55. Saleh TA, Sarı A, Tuzen M (2017) Effective adsorption of antimony (III) from aqueous solutions by polyamide-graphene composite as a novel adsorbent. Chem Eng J 307:230-238

56. Li Y, Du Q, Liu T, Peng X, Wang J, Sun J, Wang Y, Wu S, Wang Z, Xia Y, Xia L (2013) Comparative study of Methylene Blue dye adsorption onto activated carbon, graphene oxide, and carbon nanotubes. Chem Eng Res Des 91(2):361-368

57. Mohammad R, Rajoo AT, Mohamad M (2017) Coconut fronds as adsorbent in the removal of Malachite green dye. ARPN J Eng Appl Sci 12:996

58. Rani K, Naik A, Chaurasiya RS, Raghavarao K (2017) Removal of toxic Congo red dye from water employing low-cost coconut residual fiber. Water Sci Technol 75(9):2225-2236

59. Bhatti HN, Jabeen A, lqbal M, Noreen S, Naseem Z (2017) Adsorptive behavior of rice bran-based composites for malachite green dye: isotherm, kinetic and thermodynamic studies. J Mol Liq 237:322-333

60. Subramani S, Thinakaran N (2017) Isotherm, kinetic and thermodynamic studies on the adsorption behaviour of textile dyes onto chitosan. Process Saf Environ Prot 106:1-10

61. Araújo CS, Almeida IL, Rezende HC, Marcionilio SM, Léon JJ, de Matos TN (2018) Elucidation of mechanism involved in adsorption of $\mathrm{Pb}$ (II) onto lobeira fruit (Solanum lycocarpum) using Langmuir, Freundlich and Temkin isotherms. Microchem J 137:348-354

62. Wang N, Jin R-N, Omer A, Ouyang X-K (2017) Adsorption of Pb(II) from fish sauce using carboxylated cellulose nanocrystal: isotherm, kinetics, and thermodynamic studies. Int J Biol Macromol 102:232-240
63. Arami M, Limaee NY, Mahmoodi NM, Tabrizi NS (2006) Equilibrium and kinetics studies for the adsorption of direct and acid dyes from aqueous solution by soy meal hull. J Hazard Mater 135(1-3):171-179

64. Jawad AH, Rashid RA, Mahmuod RM, Ishak MAM, Kasim NN, Ismail K (2016) Adsorption of Methylene Blue onto coconut (Cocos nucifera) leaf: optimization, isotherm and kinetic studies. Desalin Water Treatment 57(19):8839-8853

65. Jawad AH, Sabar S, Ishak MAM, Wilson LD, Ahmad Norrahma SS, Talari M, Farhan AM (2017) Microwave-assisted preparation of mesoporous-activated carbon from coconut (Cocos nucifera) leaf by H3PO4 activation for Methylene Blue adsorption. Chem Eng Commun 204(10):1143-1156

66. Rashid RA, Ismail K, Sabar S (2017) High surface area mesoporous activated carbon developed from coconut leaf by chemical activation with $\mathrm{H} 3 \mathrm{PO} 4$ for adsorption of Methylene Blue. Desalin Water Treatment 74:326-335

67. Rashid RA, Jawad A, Azlan M, Ishak M, Kasim NN (2018) FeCl3activated carbon developed from coconut leaves: characterization and application for Methylene Blue removal. Sains Malaysiana 47(3):603-610

68. Baptista ATA, Silva MO, Gomes RG, Bergamasco R, Vieira MF, Vieira AMS (2017) Protein fractionation of seeds of Moringa oleifera lam and its application in superficial water treatment. Sep Purif Technol 180:114-124

69. Valix M, Cheung W, Mckay G (2004) Preparation of activated carbon using low temperature carbonisation and physical activation of high ash raw bagasse for acid dye adsorption. Chemosphere 56(5):493-501

70. Qiu H, Lv L, Pan B-C, Zhang Q-J, Zhang W-M, Zhang Q-X (2009) Critical review in adsorption kinetic models. J Zhejiang Univ-Sci A 10(5):716-724

71. do Nascimento GE, Campos NF, da Silva JJ, Barbosa CMBDM, Duarte MMMB (2016) Adsorption of anionic dyes from an aqueous solution by banana peel and green coconut mesocarp. Desalin Water Treatment 57(30):14093-14108

72. Etim U, Umoren S, Eduok U (2016) Coconut coir dust as a low cost adsorbent for the removal of cationic dye from aqueous solution. J Saudi Chem Soc 20:S67-S76

73. Ikhazuangbe P, Kamen F, Opebiyi S, Nwakaudu M, Onyelucheya O (2017) Equilibrium isotherm, kinetic and thermodynamic studies of the adsorption of erythrosine dye onto activated carbon from coconut fibre. Int J Adv Eng Res Sci 4(5)

74. Lee HC, Jeong YG, Min BG, Lyoo WS, Lee SC (2009) Preparation and acid dye adsorption behavior of polyurethane/chitosan composite foams. Fibers Polym 10(5):636-642

75. Garg V, Gupta R, Yadav AB, Kumar R (2003) Dye removal from aqueous solution by adsorption on treated sawdust. Biores Technol 89(2):121-124

76. Namasivayam C, Kavitha D (2002) Removal of Congo Red from water by adsorption onto activated carbon prepared from coir pith, an agricultural solid waste. Dyes Pigm 54(1):47-58

Publisher's Note Springer Nature remains neutral with regard to jurisdictional claims in published maps and institutional affiliations. 